University of Pennsylvania Carey Law School

Penn Law: Legal Scholarship Repository

Faculty Scholarship at Penn Law

1999

\title{
The Effect of Offer-of-Settlement Rules on the Terms of Settlement
}

Lucian Arye Bebchuk

Harvard Law School

Howard F. Chang

University of Pennsylvania Carey Law School

Follow this and additional works at: https://scholarship.law.upenn.edu/faculty_scholarship

Part of the Civil Procedure Commons, Courts Commons, Dispute Resolution and Arbitration Commons, Economic Theory Commons, Law and Economics Commons, Litigation Commons, and the Other Economics Commons

\section{Repository Citation}

Bebchuk, Lucian Arye and Chang, Howard F., "The Effect of Offer-of-Settlement Rules on the Terms of Settlement" (1999). Faculty Scholarship at Penn Law. 1393.

https://scholarship.law.upenn.edu/faculty_scholarship/1393

This Article is brought to you for free and open access by Penn Law: Legal Scholarship Repository. It has been accepted for inclusion in Faculty Scholarship at Penn Law by an authorized administrator of Penn Law: Legal Scholarship Repository. For more information, please contact PennlawIR@law.upenn.edu. 


\title{
THE EFFECT OF OFFER-OF-SETTLEMENT RULES ON THE TERMS OF SETTLEMENT
}

\author{
LUCAN ARYE BEBCHUK and HOWARD F CHANG*
}

\begin{abstract}
Under an "offer-of-settlement" rute, a party to a lawsuit may make a special offer to settle with the other party. such that if the other party rejects this offer. then this offer becomes part of the record in the case and may affect the allocation of litigation cosis. Specifically, if the parties litigate to judgment, then the allocation of litigation costs may depend on how the judgment compares with the special offer. This paper develops a model of bargaining under offer-of-settlement rules that can be used to analyze the effect that such rules have on the terms of settlement. The analysis first sets forth a general principle that identifies the settlement amount under any such rule. We then apply this principle to derive the settlement terms under the most important of these rules, and we identify a large set of seemingly different rules that produce identical settlements.
\end{abstract}

\section{INTRODUCTION}

$\prod$ HIS paper analyzes the effects of "offer-of-settlement" rules on the terms of settlement. The analysis shows that such rules can systematically shift the terms of settlement, and we derive surprisingly sharp results regarding the direction and magnitude of these shifts. The analysis also shows how we can design such rules to neutralize the advantage that parties with lower litigation costs would otherwise enjoy.

* Lucian Arye Bebchuk is the William J. Friedman and Alicia Townsend Friedman Professor of Law. Economics, and Finance at Harvard Law School. Howard F. Chang is Professor of Law at the University of Southern California Law School. This paper is a significantly revised version of our July 1992 manuscript "An Economic Analysis of Offer-of-Settlement Rules." For helpful comments. we wish to thank Ian Ayres. Jacob Glazer. Louis Kaplow. Avery Katz, Steven Shavell. Kathryn Spier, and seminar participants at the University of California, Berkeley, the University of Chicago, George Washington University, Tel-Aviv University, Yale University, the 1995 Harvard Law School conference on the economics of litigation, and the 1947 meetings of the American Law and Economics Association and of the National Bureat of Economic Research Summer Institute. Lucian Bebchuk's work has been supported by the National Science Foundation and the Harvard Law School John M. Olin Center for Law. Economics. and Business. Howard Chang's work has been supported by the James H. Zumberge Faculty Research and Innovation Fund at the University of Southern California.

[Journal of Legal Stulies. vol. XXVIII (June 1999)]

(C) 1999 by The University of Chicago. All rights reserved. (0)47-2530/99/2802-0008501,50 
Under an offer-of-settlement rule, a party to a lawsuit may make a special offer to settle with the other party, such that if the other party rejects this offer, then this offer (unlike an ordinary offer) becomes part of the record in the case and may affect the allocation of litigation costs. Specifically, if the parties litigate to judgment, then the allocation of litigation costs may depend on how the judgment compares with the special offer. The court may shift costs to the purty that fails to improve on the special offer at trial.'

Offer-of-settlement rules can vary with respect to several features: If only one party may make a special offer, which party may do so? For each party that may make a special offer, is such an offer mandatory or optional? If both the plaintiff and the defendant may make special offers, does the rule regulate the sequence in which they make these offers? If so, what order does the rule specify? For each special offer, if the offerce rejects the offer, then what are the implications for the allocation of litigation costs? For example, under one-sided cost shifting, such an offer can trigger cost shifting only in favor of the party making the offer: if an offeree who rejected the offer fails to improve on that offer at trial, then the court may require the offeree to pay the costs incurred by the other party since making the special offer. If the rule triggers two-sided cost shifting instead, then the party making the rejected offer similarly may be required to pay the corresponding costs of the offeree if the judgment at trial is less favorable to the offeror than the special offer. Thus, there is a large family of possible offerof-settlement rules.

Numerous jurisdictions in the United States have adopted such rules in order to encourage parties to settle out of court. The most notable example is Rule 68 of the Federal Rules of Civil Procedure. Like many parallel state rules, Rule 68 provides that a defendant may make a special offer of judgment. If the plaintiff accepts the offer, then the court enters judgment as specified in the offer. Otherwise, the offer can trigger one-sided cost shifting: if the plaintiff finally obtains a judgment that is not more favorable than the offer, then the plaintiff must pay the costs incurred by the defendant after making the offer. Rule 68 has been the subject of substantial debate and has provoked proposals for reform.?

Other countries also use offer-of-settlement schemes. For example, in

Similar rules may shift legal costs against parties that reject a proposed mediation award (rather than a settlement proposed by one of the parties) and then fail to improve on that proposal at trial. Henry S. Farber \& Michelle J. White, Medical Malpractice: An Empirical Examination of the Litigation Process, 22 RAND J. Econ. 199 (1991), provides an empirical analysis of medical malpractice litigation in a state that requires such mediation.

2 See. for example, Preliminary Draft of Proposed Amendments to the Federal Rules of Civil Procedure, 98 F.R.D. 339. 361-63 (1983): 102 F.R.D. 425, 432-33 (1984). 
England a defendant may make a special offer through "payment into court." "Under the English rule of cost allocation, a party that loses at trial bears the litigation costs (including attorneys' fees) of the winning party. Under the payment-into-court procedure, if the plaintiff rejects the defendant's special offer, then the plaintiff will recover costs and fees from the defendant only if it wins more at trial than the amount of the special offer. If the plaintiff wins at trial but fails to improve on the special offer, then the plaintiff must pay the costs incurred by the defendant since the date of the special ofler.

The economic analysis of Rule 68 and of simitar offer-of-settlement rules has focused on the effect of such rules un the likelihood of settlement. ${ }^{5}$ Scholars have examined the claim that rules like Rule 68 increase the likelihood of settlement. ${ }^{6}$ In contrast to this literature, our focus is on the effects of such rules on the terms of settlement.

Understanding the effects of procedural rules and institutional arrangements on the terms of settlement is very important. ${ }^{7}$ The vast majority of

See Janice Toran, Settlement, Sanctions, and Attorney Fees: Comparing English Payment into Court and Proposed Rule 68, 35 Am. U, L. Rev. 301 (1986).

${ }^{4}$ If the defendant wins at trial instead, then it will recover costs from the plaintiff according to the usual English rule of cost allocation.

"For the application of economic theory to this issue, see David A. Anderson, Improving Settlement Devices: Rule 68 and Beyond, 23 J. Legal Stud. 225 (1994); Tai-Yeong Chung, Settlement of Litigation under Rule 68: An Economic Analysis, 25 J. Legal Stud, 261 (1996); Amy Farmer \& Paul Pecorino, Can Cost Shifting Reduce the Incidence of Trial? Pretrial Bargaining in the Face of a Rule 68 Offer (unpublished manuscript, July 1996): Keith N. Hylton, Rule 68, the Modified British Rule, and Civil Litigation Reform, I Mich. L. \& Pol'y Rev. 73 (1996); Geoffrey P. Miller, An Economic Analysis of Rule 68, 15 J. Legal Stud. 93 (1986); Kathryn Spier, Pretrial Bargaining and the Design of Fee-Shifting Rules, 25 RAND J. Econ. 197 (1994). For empirical work on this question, see David A. Anderson \& Thomas D. Rowe, Jr., Empirical Evidence on Settlement Devices: Does Rule 68 Encourage Settlement? 71 Chi.-Kent L. Rev. 519 (1995); Thomas D. Rowe, Jr.. \& David A. Anderson. OneIVay Fee Shifting Statutes and Offer of Judgment Rules: An Experiment, 36 Jurimetrics J. 255 (1996): Thomas D. Rowe. Jr.. \& Neil Vidmar. Empirical Research on Offers of Settlement: A Preliminary Report, 51 Law \& Contemp. Probs. 13 (1988).

${ }^{5}$ The important paper by Spier, supra note 5 . for example, examines pretrial bargaining under asymmetric information to see if cost-shifing rules based on the settlement offers made by the parties lead to more settlement. In a mechanism-design framework, she concludes that cost shifting based on offers of settlement would yield a higher settlement rate than any other cost-shifting rule a court could adopt. The threat of cost shifting deters the parties from making extreme settlement offers and encourages them to negotiate in good faith. Thus, under offer-of-settlement rules, special ofters are more credible signals of the offeror's beliets. By facilitating the exchange of credible information, these rules can increase the likelihood of sertlement.

For a general discussion of the importance of gaining such an understanding. see Lucian A. Bebchuk. On the Difference between Settlement Terms and the Expected Judgment (unpublished manuscript, 1997). 
cases end in settlement rather than in judgment. The min impact of the law on outcomes (and in turn on ex ante behavior) is therefore not directiy through judgments rendered by courts but rather indirecty by shaping the terms of settlements. Thus, identifying the effects of the legal system on settlement terms is important for any positive or nomative analysis of the outcomes produced by the system.

This paper prwides a framework for identifying the forms of settement

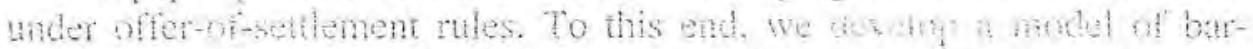
gaining that cun bo used to identify the setlement who expocted under such rules." Indecd. the paper derives a general result that enables us to identify the expected settement tems under any given ollit-of-setilement rule. We then apply this result to derive the outcomes under the most important of these rules.

An essential eiement of the framework we will develop is the effect of a special offer on any subsequent bargaining between the parties. If an offeree rejects a special offer, this rejection does not imply that the parties will not settle. The parties may still subsequently make ordinary settlement offers, as they could in the absence of a special offer, and thereby reach a settlement. The parties will conduct these settlement negotiations, however, in the shadow of a different threat point than they would in the absence of a special offer. The presence of a special offer will affect the expected payoffs for the parties if the case goes all the way to judgment at trial. Therefore, the outcome of the bargaining game that the parties would play if an offeree rejects a special offer is a function of the settlement amount proposed in the special offer. Thus, an offeror would make a special offer in light of its anticipated effect on subsequent bargaining.

The identification of the settlement amount expected under any given offer-of-settlement rule will enable us to examine (i) which party benefits from each rule. and (ii) how the settlement amount compares with the expected judgment (that is, the mean amount that the parties expect the plaintiff to win at trial). The analysis shows. surprisingly. that a large set of seemingly different rules produce identical setlements.

Our model has important implications for both postive and normative analysis. The model enables us to derive not only the settlement outcomes that emerge under existing offer-of-settlement rules but also those that would occur under proposed offer-of-settement mes (should they be adopted). This analysis is essential for any positive account of the outcomes

In contrast to other papers that consider these setlement teras. such as Millet. supra note 5. and Anderson. stupe note 5. we explicitly model the process of barquing between the parties. 
produced by legal rules as well as for any normative evaluation of performance of these rules in producing desired outcomes.

One normative implication that we explore is the following. Parties often differ considerably in their litigation costs. ${ }^{9}$ In the absence of an offer-ofsettlement rule, settlement amounts can be expected to deviate from the expected judgment in favor of the party with lower litigation costs. If the expected judgment in a case is the best available proxy for the onteone that

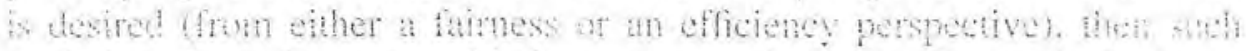
weviatuns from the expected judgnent are undesinable. Otr analys shews how, under some common circumstances, we can design offer-of-setticnein rties to eliminate the bargaining advantage that the party with lower litgition costs would otherwise enjoy. Furthermore, to design these rules to accomplish this goal, public officials would not need to know in advance which party has the lower litigation costs. While we find the possible use of offer-of-settlement rules to neutralize the bargaining advantage of parties with lower litigation costs quite interesting, we wish to emphasize that, for the reasons discussed earlier, analysts who have no interest in this particular goal should still find relevant our general analysis of how offer-ofsettlement rules affect settlement terms.

The analysis in this paper is organized as follows. Section II presents our framework of analysis. Section III analyzes bargaining both with and without offer-of-settlement rules and puts forward the basic lemma that subsequent sections will use to identify the outcome under particular offerof-settlement rules, Section IV analyzes the case of one special offer and one-sided cost shifting, Section $V$ analyzes the case of one special offer and two-sided cost shifting, and Section VI analyzes the case in which each side makes a special offer. Section VII addresses an important extension of the model. Section VIII considers the implications of the model for the outcomes under the existing Rule 68 and for the design of offer-of-settlement rules. Finally. Section IX concludes.

\section{FRAMEWORK OF ANALySis}

Suppose that a risk-neutral plaintiff files a suit against a risk-neutral defendant at time $t=0$. Assume that unless the parties settle out of court, the court will render judgment. If the parties proceed all the way to judgment. then in the intervening time, the plaintiff incurs positive litigation costs in

\footnotetext{
"For example, in some tort cases the defendant might face iower costs because of greater ixpertise or aceses to information. whereas in other tort cases the defendan migh face higher fitigation costs because a trial would distupt the defendint's operations.
} 
the amount $C_{\mathrm{p}}$, and the defendant, in the amount $C_{\mathrm{d}}$. The parties may incur different litigation costs. For example, they may differ in terms of the costliness of the evidence they must produce in court or in terms of how disruplive they find litigation to be. Let $C$ denote the total litigation costs: $C=$ $C_{\mathrm{f}}+C_{\mathrm{i}}$.

Assume that there are $n$ stages to the litigation process, from the filing of at suit to judgment at trial, and that the parties' litigation costs are spread whet these in stages. At each stage $i=1 \ldots \ldots, n$, each party incurs some portion of its total litigation costs. Let $c_{p}^{i}$ and $c_{\mathrm{s}}^{i}$ lenote the litigation expenWittes in stage $i$ by the plaintiff and by the defendant, respectively. Assume that the court cain observe these litigation costs and can therefore allocate these costs between the parties according to any applicable cost-shifting rule." Assume that the parties have identical discount rates and that all money values are expressed in terms of their present discounted value at time $t=0$.

Both parties share the same expectation regarding the outcome at trial. Let us assume at first that the defendant concedes liability and the parties dispute only the amount of damages that the defendant should pay the plaintift. Let $D$ represent the damages that the court would award to the plaintiff at trial. From the perspective of the parties, $D$ will be a random variable. Let $\bar{D}$ denote the expected value of $D$, where $\bar{D}>0$. Assume that $D$ is distributed according to a continuous probability density function $f(D)$. Assume also that the probability that $D$ exceeds its mean equals the probability that it does not: that is, assume that $\operatorname{pr}(D \leq \bar{D})=\operatorname{pr}(D>\bar{D})=1 / 2$. We will later extend our analysis to include skewed distributions, for which $\operatorname{pr}(D \leq \bar{D}) \neq 1 / 2$, as well as disputes over liability.

Let $J$ represent the total amount that a judgment at trial would require the defendant to pay to the plaintiff. Under an offer-of-settlement rule, this judgment may include a cost-shifting element in addition to damages: $J$ may include a positive amount in order to reimburse the plaintiff for its litigation costs. or $J$ may include a negative amount in order to reimburse the defendant for its litigation costs. The amount $J$ will be uncertain because $D$ is a random variable and cost shifting under an offer-of-settlement rule will tum on the value of $D$. Even in the absence of any offer-of-settlement rule, $J$ will be a random variable, because then $J=D$.

The parties may make ordinary offers to settle out of court without invoking any offer-of-settlement rules. As is customary in the bargaining the-

\footnotetext{
19. We can extend our analysis to include cases in which the court can observe and shift only part of these litigation costs. We analyzed such an extension in an earlier draft of this paper. which is available from the authors upon request. We also consider partial cost shifting in Settion VIII. in which we consider the effects of the existing Rule 68.
} 
ory literature, assume that the parties would make ordinary offers in a sequence of bargaining rounds. In particular, assume that before each stage of the litigation process, there would be a bargaining round in which one party would make an ordinary offer and the other party would either accept or reject the offer, the identity of the party making the offer would be determined randomly at the start of the round, and each party would be equally likely to be the ofteror. If the offeree rejects the offer, then the partics would begin the nex stage of the litigation process. in which the partice would incur another fraction of their litigation costs, and the partics would enter another round of bargaining.

Given that the parties are risk neutral, the defendant seeks to minimize its expected costs (its litigation costs plus any payment to the plaintiff). and the plaintiff seeks to maximize its expected payoff (any payment from the defendant minus its litigation costs). Assume that the parties have no mechanism (such as a repeat player might develop by cultivating a reputation for intransigence) that would enable them to bind themselves to a particular bargaining strategy. That is, neither party can commit credibly to a strategy of intransigence, which would enable it to obtain a larger fraction of the gains from settlement. Thus, each party would accept an offer if and only if it were unable to improve its expected payoff by rejecting the offer instead.

For simplicity, assume that an offeror under any applicable offer-ofsettlement rule makes a special offer at time $t=0$ before the first stage of the litigation process, before the parties incur any litigation costs, and before the first round of ordinary bargaining. We can extend the analysis to include the case in which special offers can be made at later points in time. ${ }^{11}$ Given the opportunity to make a special offer, the offeror would choose to make an offer if and only if it were unable to improve its expected payoff by doing otherwise.

The structure of the bargaining game described above, including $n, \bar{D}$, $f(D)$, and $c_{d}^{i}$ and $c_{p}^{\prime}$ for $i=1, \ldots, n$, as well as any applicable offer-ofsettlement rule, is common knowledge to the participants. This assumption ensures that settlement occurs with certainty and always occurs before the parties incur any litigation costs. ${ }^{2}$ The assumption of perfect information allows us to focus on the issue that we are interested in studying: the effect of various offer-of-settlement rules on settlement amounts.

11 In an earlier draft of this paper. which is available from the authors upon request. we explored such an extension and found that as long as both parties can make special offers. the option of making them later rather than sooner does not change the outcome.

12 A plaintiff will choose to file at suit only if it expects a positive payoff from doing so. We may assume that the cases considered in this model are only hypothetical, and we would only actually observe suits in those cases in which the expected settlement is positive. 
It will prove useful to refer to a more specific example throughout our analysis. For this purpose, suppose that $C_{\mathrm{p}}=60, C_{\mathrm{d}}=20$, and $D$ is uniformly distributed in the interval $(60,140)$, so that $\bar{D}=100$. We will use this numerical example to illustrate our results below.

\section{IIi. Bargaining with and wifhout Special OfFers}

In this section, we examine the ontome of barguining under two different regimes. First. we analyze bartaming in the absence of offer-ofsettement rules. Second. we will introduce the possibility of invoking offer-of-settlement rules.

\section{A. Bargaining without Ofjer-of-Sethement Rules}

Consider bargaining in the absence of any offer-of-settlement rules. Let $B$ represent the expected outcome of such an ordinary bargaining game. That is, let $B$ denote the amount that the defendant can expect to pay the plaintiff in a settlement, which we can express as a function of $\bar{D}$. We can derive the expected settlement amount $B(\bar{D})$ as the solution to this bargaining game.

Proposition 1. The parties will settle in the first round of bargaining, and the expected settlement amount would be

$$
B(\bar{D})=\bar{D}+1 / 2\left(C_{\mathrm{d}}-C_{\mathrm{p}}\right) .
$$

Proof. We prove this proposition by backward induction. As in the sequential bargaining game analyzed by Ariel Rubinstein, the party making the offer in any given round would make the offer that is the least favorable to the other party among all the offers that the other party would find acceptable. ${ }^{13}$ This offer gives the other party the payoff that it would receive if it rejected the offer and went on to the next round of bargaining.

For example, suppose that the parties reach round $n$. If the plaintiff makes the offer in round $n$, then the plaintiff would demand an amount $\bar{D}+c_{\mathrm{d}}^{n}$. and the defendant would agree to pay it. If instead the defendant makes the offer in round $n$, then the defendant would offer to pay an amount $\bar{D}-c_{p}^{n}$, and the plaintiff would accept the offer. Because each outcome is equally likely ex ante, the expected value of the settlement, conditional on the parties reaching round $n$, will be $\bar{D}+1 / 2\left(c_{d}^{\prime \prime}-c_{\mathrm{p}}^{\prime \prime}\right)$.

Suppose the parties reach round $n-1$. The settlement offers they would make would anticipate the expected value of a settlement in round $n$ if the offer in round $n-1$ were rejected. Thus, if the plaintiff makes the offer,

See Ariel Rubinstein. Perfect Equilibrium in a Bargaining Model. 50 Econometrica 97 $(1982)$. 
it would demand an amount $\bar{D}+1 / 2\left(c_{d}^{n}-c_{p}^{n}\right)+c_{d}^{n-1}$, and the defendant would agree to pay it. If the defendant makes the offer, it would offer to pay $\bar{D}+1 / 2\left(c_{t}^{n}-c_{p}^{n}\right)-c_{p}^{n-1}$, and the plaintiff would accept the offer, Because each outcome is equally likely ex ante, the expected value of the settement. conditional on the parties reaching round $n-1$. will be $\bar{D}+$ $1 / 2\left(c_{\mathrm{d}}^{n}+c_{\mathrm{d}}^{j-1}-c_{\mathrm{p}}^{n}-c_{\mathrm{p}}^{n-1}\right)$. Continuing this reasoning to round 1 , we arrive at the expected settlement amoum set forth above in (1). Q.E.D.

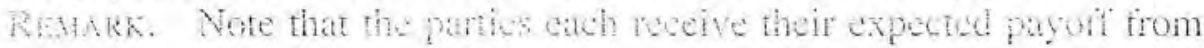
whit (net of litigation costs) plus a shate of the surplus obianed through agreenent. They divide this sumplus-that is, the total litigation costs wroided by setlement, $C=C_{d}+C_{p}$ - equally. This outcome is the same as under the Nash bargaining solution. ${ }^{15}$

The settlement outcome will be more favorable to the plaintiff than one would expect the judgment itself to be if and only if $C_{d}>C_{p}$. Conversely, the settlement would be less favorable to the plaintiff if and only if the opposite inequality holds. Compared with the expected judgment $\bar{D}$, the expected settlement amount $B(\bar{D})$ will favor the party with lower litigation costs.

EXAMPLE. To illustrate this effect, consider our numerical example, in which $C_{\mathrm{d}}<C_{\mathrm{p}}$. In that case, the expected settlement would be $B(\bar{D})=80$, which is less than 100 , the expected judgment. Thus, $B(\bar{D})<\bar{D}$, and compared to the expected judgment, the expected settlement would favor the defendant.

\section{B. Bargaining with Offer-of-Settlement Rules}

Let us now turn to bargaining under an offer-of-settlement rule. We will start by setting forth a general result that will enable us to predict the outcome under any given offer-of-settlement rule. The subsequent analysis will

It Furthermore. if the litigation costs in the first stage. $c_{j}^{1}$ and $c_{p}^{1}$, are a small proportion of the total litigation costs, then litte will turn on which party gets to make the offer in the first found, and the actual settlement will be correspondingly close to the expected settlement amount $B(\bar{D})$.

15. The Nash bargaining solution is a cooperative same solution. Robent Cooter introduced it to the litigation context and has used it extensively in this context. See. for example. Robert Cooter. Toward a Market in Unmatured Tort Claims. 75 Va. L. Rev. 383 (1989); Robert Cooter \& Thomas Ulen. Law and Economics (1988). Our model follows the noncooperative approach to bargaining, which. unlike the cooperative approach, seeks to model explicitly the bargaining process. As envisioned by Nash. the outcome of noncooperative models is often equivalent to that predicted by the "black-box" models of the cooperative approach. For an analysis of the relationship between cosperative and noncooperative models. see Ken Bimmore. Ariel Rubinstein. \& Asher Wolinsky. The Nash Barganing Solution in Economic Modeliing. 17 RAND J. Econ. 176 (1986). 
use this basic lemma to derive the settlement outcome under several specific offer-of-settlement rules.

Suppose that one party may make one special offer at time $t=0$, immediately before the first round of ordinary bargaining and belore the first stage of litigation. First, let us assume that only one party may make such an offer and that this party will indeed make this offer. Let $S$ denote the amount proposed in this special offer. Later, in Section VI. we will exiend wa analysis to two-party rules, under which hoth partes can make specint whers.

The hey point to recognize is that if the special offer were rejected, this rejection would not necessarily mein that the case would not be settled; the parties might still make ordinary settlement offers and thereby reach a settlement. The parties will conduct these settlement negotiations, however, in the shadow of a different expected judgment than they would in the absence of a special offer. Under an offer-of-settlement rule, the special offer will affect the payoffs that the parties can expect if the case ends in a judgment at trial. Specifically, if the special offer $S$ is rejected, then the judgment $J$ may include a cost-shifting element, depending on how $D$ compares with $S$. Thus, the judgment will be a function of $S$ : let $J(S)$ represent the judgment from trial, including the cost shifting due under the relevant offerof-settlement rule given the special offer $S$. Let $B$ again denote the payoff to plaintiff from the ordinary bargaining game, in this case, the ordinary bargaining game that the parties would play if an offeree rejected a special offer. The outcome $B$ is still a function of the expected judgment, but $E[J]$ is no longer simply $\bar{D}$, the expected damages, because $J$ is now a function of $S$.

Consider the effect of an increase in $S$ on the judgment $J(S)$. In those cases in which $S$ changes from an amount less than $D$ to an amount greater than or equal to $D$, liability for $C_{\mathrm{d}}$ will shift to the plaintiff, or liability for $C_{p}$ will shift back to the plaintiff, or both, depending on which costs shift under the offer-of-settlement rule. In all other cases. the increase in $S$ will not affect $J(S)$. Therefore, the expected judgment, denoted $E[J(S)]$, taking the expectation with respect to different possible values of $D$, is a nonincreasing function of $S$.

Thus, $B$ is now a function of the settlement amount $S$ proposed in the special offer, because $B$ is a function of $E[J(S)]$. Let $B(S)$ denote this function, and let $S^{*}$ denote the optimal special offer for the offeror. We can now show the following lemma:

LEMma 1. If one party makes a special offer of settlement, then it can maximize its own payoff by choosing the $S$ that equals the payoff to the plaintiff from the ordinary bargaining game that the parties would play if the offeree were to reject the special offer. That is. 


$$
S^{*}=B\left(S^{*}\right),
$$

which implies

$$
S^{*}=E\left[J\left(S^{*}\right)\right]+1 / 2\left(C_{\mathrm{d}}-C_{\mathrm{p}}\right) .
$$

The offeree would accept this special offer.

Proof. By analogy to proposition 1, we know that

$$
B(S)=E[. /(S)]+1 / 2\left(C_{d}-C_{p}\right) \text {. }
$$

It the offeree rejects $S$, then the parties immediately begin ordinary bargaining. The Nash hargaining solution, like that described in proposition 1 , results from this ordinary bargaining game. The same proof applics, where the expected judgment $E[J(S)]$ substitutes as a generalization of the expected damages $\bar{D}$.

Equality (2) follows from the behavior of the parties as they seek to maximize their payoffs. For example, suppose the plaintiff makes the special offer. Given (4), we know that $B^{\prime}(S) \leq 0$, because $E[J(S)]$ is a nonincreasing function of $S$. The plaintiff knows that if it demands $S$, it will receive $S$ immediately if $S \leq B(S)$, because the defendant would accept such a special offer, but $B(S)$ immediately if $S>B(S)$, because the defendant would reject such a special offer. That is, the plaintiff receives $\min [S, B(S)]$. Given that $B^{\prime}(S) \leq 0$, the plaintiff could maximize this payoff, $\min [S, B(S)]$, by choosing $S$ such that $S=B(S)$. The plaintiff can improve the terms of a settlement by increasing the demand $S$, but the plaintiff would choose to do so only as long as the defendant would still agree to the demand. To raise it any higher would not only entail rejection but also reduce the plaintiff's payoff from such a rejection (because it increases the likelihood of unfavorable cost shifting). Thus, the plaintiff chooses the $S$ that is so large as to be barely acceptable to the defendant.

Suppose instead that the defendant makes the special offer. By similar reasoning, the defendant would have to pay $\max [S, B(S)]$ and could minimize the plaintiff's payoff by choosing $S=B(S)$. Thus, (2) holds whether the plaintiff or the defendant makes the special offer. ${ }^{16}$ Finally, (3) follows from (2) and (4). Q.E.D.

REMARK. Figure 1 illustrates why $S=B(S)$ is the optimal offer for either party to make. ${ }^{17}$

if If $B(S)$ is constant at the $S$ that solves (2), then there may be a range of $S$ values that yield the same payoffs for the parties. The party making the special offer would be indifferent between the solution to (2) and any of these other possible special offers. Assume for simplicity that the party would always choose the solution to (2).

17. After developing our lemma, we learned about an independent effort by Farmer and Pecorino, supra note 5 , who develop a model of one particular offer-bf-seulement rule (a defendant-only rule like Rule 68) and focus on its effects on the incentives to settle. Farmer and Pecorino use a similar figure to illustrate a result similar to our lemma, but they state 


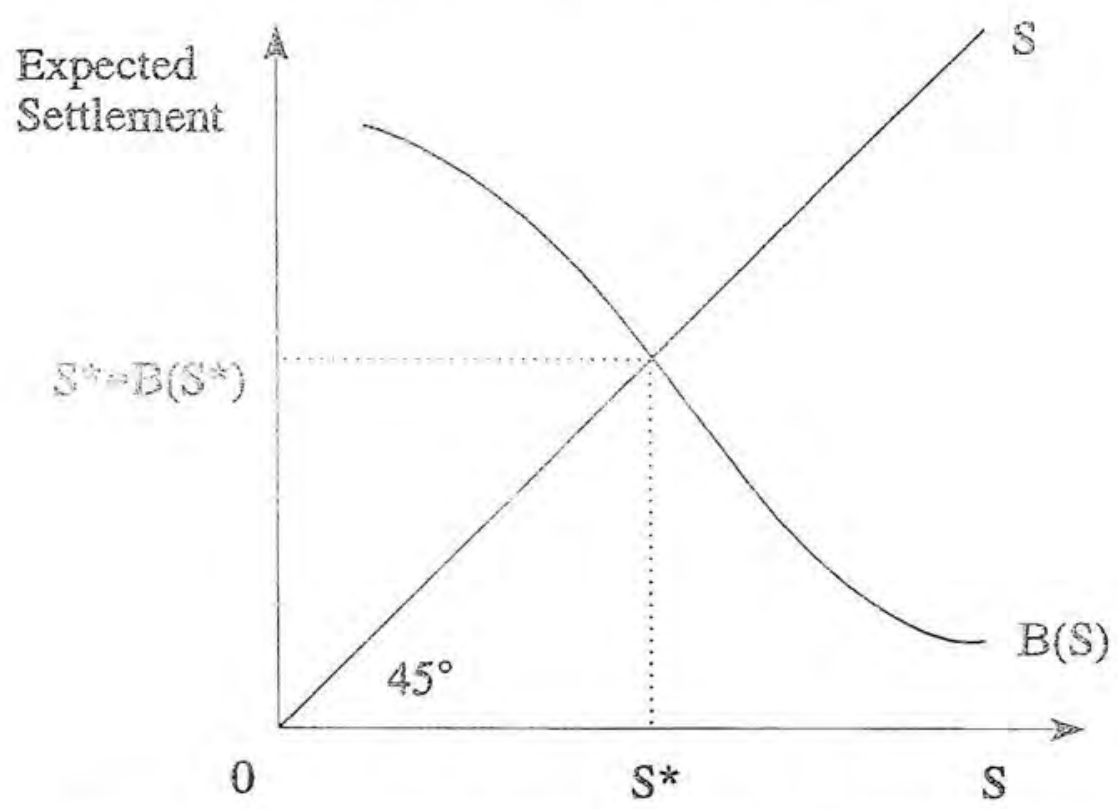

Figure 1.-The expected settlement as a function of the special offer $S$

The function $B(S)$ represents the plaintiff's payoff if the offeree rejects the special offer and the parties instead settle through ordinary bargaining. $B(S)$ is a nonincreasing function of $S$, because a larger $S$ increases the plaintiff's expected litigation costs under an offer-of-settlement rule. The 45 -degree line represents $S$, which is the plaintiff's payoff if the offeree accepts the special offer $S$.

If the plaintiff makes the special offer $S$, then the defendant would choose $S$ if $S \leq B(S)$ and $B(S)$ otherwise. Thus, the plaintiff's payoff as a function of $S$ would be $\min [S, B(S)]$, represented by the lower envelope of $S$ and $B(S)$. The plaintiff would maximize this function, $\min [S, B(S)]$. by choosing the $S$ identified by the intersection $S=B(S)$.

Similarly, if the defendant makes the special offer $S$, then the plaintift would choose $S$ if $S \geq B(S)$ and $B(S)$ otherwise. Thus, the plaintiff's payoff as a function of $S$ would be $\max [S, B(S)]$, represented by the upper envelope of $S$ and $B(S)$. The defendant would minimize this function, $\max [S, B(S)]$, by choosing the $S$ identified by the intersection $S=B(S)$.

this result in at form specific to their model of a particular offer-of-settement rule. with only one special offer by the defendant and one ordinary offer by the plaintiff. Our lemma is more general: it applies to either party under a wide variety of offer-of-settlement rules and allows for more complex bargaining games. 


\section{One Special Offer with One-Sided Cost Shifting}

We will now apply the general principle set forth in lemma 1 to derive the settlements that emerge under particular offer-of-settlement rules. Offerof-settlement rules may provide for cost shifting only in one direction, or they may provide for two-sided cost shifting. In this section, we assume that the offer-of-settlement rule would shift costs only in favor of the party making the special offer. For example. suppose the defendant makes a special offer $S$. Under an offer-of-setlement rule shifting costs only in favor of the defendant, the plaintiff would be obliged to pay $C_{4}$ to the defendant if the damages $D$ are less than or equal to $S$.

\section{A. Defendan Makes the Special Otfer}

First, we will consider a one-sided cost-shifting rule that allows the defendant to make one special offer. We will show that whether the rule requires such an offer or, like Rule 68, merely permits one, the outcome will be the same. Subsequently we also address the case in which the plaintiff may make the only special offer.

Proposition 2. If an offer-of-settlement rule with one-sided cost shifting permits the defendant to make a special offer, then:

(a) The defendant will always choose to exercise this option, and the plaintiff will accept the special offer.

(b) The settlement amount $S^{*}$ will solve

$$
S^{*}=\bar{D}+1 / 2\left(C_{\mathrm{d}}-C_{\mathrm{p}}\right)-C_{\mathrm{d}} \operatorname{pr}\left(D \leq S^{*}\right) .
$$

(c) The settlement amount will be (i) no greater than the expected settlement amount without the offer-of-settlement rule and (ii) strictly less than the expected damages $\bar{D}$.

Proof. Let us first prove proposition 2(b). Suppose the defendant chooses to make a special offer $S$. In this case, the defendant pays the plaintiff $D-C_{\mathrm{d}}$ if $D \leq S$, but pays $D$ otherwise. Because the court subtracts $C_{\mathrm{d}}$ from its judgment if and only if $D \leq S$, the expected value of the judgment equals

$$
E[J(S)]=\bar{D}-C_{\mathrm{d}} \operatorname{pr}(D \leq S) .
$$

Note that $E[J(S)]$ is nonincreasing in $S$ (and strictly decreasing in $S$ as long as $\operatorname{pr}(D=S)>0$ ). Given (6), lemma 1 implies that the optimal special settlement offer for the defendant, $S^{*}$, solves equation (5).

Note that (5) implies

$$
S^{*} \leq \bar{D}+1 / 2\left(C_{\mathrm{d}}-C_{\mathrm{p}}\right)
$$


and together with proposition 1 , inequality (7) implies proposition 2(c)(i). Moreover, as long as $\operatorname{pr}\left[D \leq \bar{D}+1 / 2\left(C_{\mathrm{d}}-C_{\mathrm{p}}\right)\right]>0$, then $S^{*}=\bar{D}+$ $1 / 2\left(C_{\mathrm{d}}-C_{\mathrm{p}}\right)$ will be inconsistent with (5) and the inequality in (7) must hold strictly. Thus, the defendant will always be willing to make a special offer, which the plaintiff will accept immediately, and the defendant will thereby pay no more than it would in the absence of the offer-of-settlement rule. In general, the defendant will benefit hom invoking such a rule. Thus. propoation $2(a)$ follows, becatse the defendant would make a spociat oflet as bing as this offer would yield its manum pussible payolf.

Finally, to prove proposition $2(c)(i i)$, suppose $S=\vec{D}$. Given that pro $D \leq$ $D)=1 / 2$, it would follow that $(-4)$ and $(6)$ would imply that $B(S)=$ $\bar{D}-1 / 2 C_{p}$. In this case, $B(S)<S$, and $(2)$ implies that the defendant would prefer to reduce $S$ in order to minimize its liability. Thus, the defendant will always make a special offer $S^{*}<\bar{D}$, which the plaintiff will accept immediately. Q.E.D.

REMARK. One-sided cost shifting can never hurt an ofteror who invokes an offer-of-settlement rule: the offeror might win reimbursement but would never have to reimburse the offeree. Thus, given the option of making a special offer under a one-sided cost-shifting rule, the defendant would always choose to make such an offer. Therefore, when cost shifting is onesided, it makes no difference whether the rule requires or merely permits the defendant to make a special offer. Furthermore, because the defendant cannot harm its bargaining position by making a special offer under such an offer-of-settlement rule, the settlement it can obtain by invoking the rule will never be less favorable to the defendant than the expected settlement in the absence of such a rule.

By making a special offer under a one-sided cost-shifting rule, the defendant can also obtain a settlement for less than $\bar{D}$, the damages expected at trial. The defendant can do so because a specia! offer of $\bar{D}$ under such a rule would give the defendant a threat point to its advantage: if $S=\bar{D}$, then each side would be equally likely to bear $C_{1}$ under the cost-shifting rule, but only the plaintiff could bear $C_{p}$. Given the threat of an outcome worse than $\bar{D}$ for the plaintiff, the plaintiff would be willing to accept a special offer below $\bar{D}$.

Example. Consider our numerical example again. In that example, $D$ is uniformly distributed in the interval $(60,140)$, and therefore

$$
\operatorname{pr}(D \leq X)=X / 80-3 / 4
$$

for $60 \leq X \leq 140$. Using (8) and our specific values for $\bar{D}, C_{\mathrm{d}}$, and $C_{\mathrm{p}}$ to substitute in (5) and solving for $S^{*}$ yields $S^{*}=76$. Thus, $S^{*}$ is not only less than the expected damages, $\bar{D}=100$, but also less than the settlement under ordinary bargaining in the absence of a special offer, $B(\bar{D})=80$. 


\section{B. Plaintiff Makes the Special Offer}

Suppose now that the plaintiff makes the special offer to settle for an amount $S$. Consider an offer-of-settlement rule shifting costs only in favor of the plaintiff. Specifically. suppose the defendant would be obliged to pay $C_{\mathrm{p}}$ if the damages $D$ are greater than $S$. The same intuition set forth above upplies by analogy to this case. By the sane retaning used to prove proposition 2. wo can show the following:

Proposmons 3. If an offer-ot-sertement atle with one-sided cost shifting permits the plaintiff to make a special ofter. then:

(a) The plaintif will always choose io exercise this option, and the defendant will accept the special offer.

(b) The scticment amount $S *$ will soive

$$
S^{*}=\bar{D}+C_{\mathrm{p}} \operatorname{pr}\left(D>S^{*}\right)+1 / 2\left(C_{\mathrm{d}}-C_{\mathrm{p}}\right) .
$$

(c) The settlement amount will be (i) at least the expected settlement amount without the offer-of-settlement rule and (ii) strictly greater than the expected damages $\bar{D}$.

\section{One Special Offer with Two-Sided Cost Shifting}

With two-sided cost shifting, it is no longer unambiguously in a party's interest to make a special offer to settle, because such an offer will entail the risk that costs will shift against that party. Consider first a scheme in which such an offer is mandatory for the party in question. We will subsequently consider a scheme in which the party chooses whether to make such an offer.

\section{A. Mandatory Offers}

Suppose that either the defendant or the plaintiff must inake a special ofter: Applying lemma 1, we can show the following.

Proposition 4. If an offer-of-settlement rule with two-sided cost shifting requires either party to make a special offer, then the settlement amount will be $S^{*}=\bar{D}$.

Proof. Given a special offer for an amount $S$.

$$
\begin{aligned}
E[J(S)] & =\bar{D}-C_{\mathrm{a}} \operatorname{pr}(D \leq S)+C_{\mathrm{p}} \operatorname{pr}(D>S) \\
& =\bar{D}+C_{\mathrm{p}}-C_{\operatorname{pr}(D \leq S) .}
\end{aligned}
$$

because the plaintiff receives $C_{0}$, if and only if $D>S$, and pays $C_{\mathrm{d}}$ if and only if $D \leq S$. Note that again $E[J(S)]$ is nonincreasing in $S$ (and strictly decreasing in $S$ as long as $\operatorname{pr}(D=S)>0$. 
Using (10) and lemma 1, we find the optimal special offer $S$ * for either party must solve the equation

$$
S^{*}=\bar{D}+1 / 2\left(C_{\mathrm{d}}-C_{\mathrm{p}}\right)+C_{\mathrm{p}}-C \operatorname{pr}\left(D \leq S^{*}\right) .
$$

which implies

$$
S^{*}=\bar{D}+C\left[1 / 2-\operatorname{pr}\left(D \leq S^{*}\right)\right] .
$$

Given that $\operatorname{pr}(D \leq D)=1 / 2$, we find $S^{*}=\bar{D}$ is the intulie solution for cquation (12). Therefore the optimal special offer for cither party will always equal D. Q.E.D.

Remakk. To see the intuition for this result, consider out numerical example. Suppose the defendant must make a special ofler. It the defendant offers 100 and the plaintiff rejects this offer, then the parties will be equally likely to bear any litigation costs. Once the scheme incorporates iwo-sided cost shifting, it no longer matters which party would have larger litigation costs. Instead, expectations regarding the final allocation of the total litigation costs $C$, which would turn upon the trial outcome, will determine the terms of settlement under any subsequent ordinary bargaining. If either party makes a special offer of 100 , then each side would be equally likely to bear these litigation costs, and therefore the expected judgment is simply 100. Thus, the parties will settle for 100 whether the offeree accepts or rejects the special offer.

Can the defendant gain by making a special offer that does not equal 100? The defendant cannot gain by making any offer greater than 100 , because the plaintiff would accept such an offer, ${ }^{18}$ and as a result the defendant would have to pay more than 100 . If the defendant made a special offer of less than 100, then the plaintiff would reject. The defendant would then be more likely than the plaintiff to bear any litigation costs, the expected judgment would be greater than 100, and the threat point would favor the plaintiff in the ordinary bargaining that would follow. Thus, the defendant would expect to pay more than 100 in the settlement that would follow rejection of a special offer of less than 100.

Finally, if the plaintiff rather than the defendant makes the special offer. the same logic applies. If the plaintiff makes a special offer of 100 , then the plaintiff will obtain 100 in a settlement. If the plaintiff were to make any other special offer, then the plaintiff would receive less than 100 in a settlement. ${ }^{19}$

Rejection by the plaintiff would only make the plaintiff more likely than the defendant to bear any litigation costs. so that the expected settlement in any subsequent ordinary bargaining would be less than 100 .

"In this sense, two-sided cost shifting restores symmetry to the bargaining power of the parties in settement negotiations. The special offer of settement eliminates any effect that a difference in litigation costs, $C_{d}-C_{p}$, would have on the settlement imount. 


\section{B. Optional Offers}

If the use of the offer-of-settlement rule is optional, then a party's decision on whether to invoke the rule will depend on whether a special offer would improve the terms of settlement for the offeror. If the effect on these terms favors the defendant, then the defendant will gain from invoking an offer-of-settlement rule, but the plaintiff will not. If this effect favors the plaintifl instead, then the plaintiff will prefer to use such a rule, but the delendant will preter not to do so. Thus:

Propositios 5. If an offer-of-settlement rule with two-sided cost shifting permits but does not require the party in question to make a special offer, then the party will make such an offer if and only if its litigation costs are higher. Specifically;

(a) The defendant would choose to make a special offer if and only if $C_{\mathrm{d}}>C_{\mathrm{p}}$.

(b) The plaintiff would choose to make a special offer if and only if $C_{\mathrm{p}}>C_{\mathrm{d}}$.

If the party that has the option elects to make a special offer, then the settlement will be $S^{*}=\bar{D}$.

Proof. We know from proposition 4 that by making a special offer under a two-sided cost-shifting rule, either party can obtain a settlement for $\bar{D}$. Given the option of making such an offer, a party would choose to do so if and only if $\bar{D}$ is better for the offeror than the settlement it could obtain in the absence of a special offer, which we know from proposition 1 would yield the amount $\bar{D}+1 / 2\left(C_{\mathrm{d}}-C_{\mathrm{p}}\right)$. Thus, a special offer would eliminate the disadvantage that a party suffers as a result of higher litigation costs, and each party finds that a special offer improves its payoff if and only if it has higher litigation costs than the other party. Q.E.D.

REMARK. If we wanted to ensure that the parties settled for an amount equal to the expected damages, we could do so using either one of two offer-of-settlement rules: (i) we could require either one of the parties to make a special offer that would trigger two-sided cost shifting, or (ii) we could give the party with higher litigation costs the option of making such an offer. We could implement the second rule only if we know how $C_{p}$ and $C_{d}$ compare. The first rule does not require such knowledge.

\section{Special Offers by Both Plaintiff and Defendant}

In this section, we allow up to two special offers, $S_{\mathrm{p}}$ and $S_{\mathrm{d}}$, by the plaintiff and by the defendant, respectively. Specifically, first one party may or must make a special offer. If the first party does not make a special offer, or if the second party rejects the special offer, then the second party may or must make a special offer. Assume that the second party can reject the 
first special offer and make a second special offer immediately. If neither party accepts a special offer, then the parties immediately enter the first round of ordinary bargaining.

Given one or both of these special offers, the offer-of-settlement rule then provides for possible cost shifting if the parties litigate to judgment. If $D>S_{\mathrm{p}}$, then the defendant remburses the plaintiff for its litigation costs. If $D \leq S_{4}$, then the plainilf remburses the defendant for its litigation costs. If $S_{4}<D \leq S_{p}$, then the phath pays the defendunt's costs if and only if the plaintill's special ofier thiggers iwo-sided cost shifting, and the defendant pays the plaintifl's cosis if and only if the defendant's special offer iriggers two-sided cost shititing.

We will refer to all offer-of-settlement rules fitting the description set forth above as "two-party" rules. Let $S_{1}$ denote the first special offer, and if the second party rejects that offer and makes a second special offer, let $S_{2}$ denote the second special offer. That is, let $S_{i}$ represent the special offer by party $i$, whether party $i$ is the plaintiff or the defendant, and let $S_{i}^{*}$ denote the optimal special offer for party $i$.

The structure we have described includes many possible two-party rules, which vary with respect to whether

(1) the plaintiff or the defendant is the first party to move,

(2) the rule requires or merely permits the first party to make a special offer,

(3) the first special offer triggers one-sided or two-sided cost shifting,

(4) the rule requires or merely permits the second party to make a special offer, and

(5) the second special offer triggers one-sided or two-sided cost shifting. Thus, there are 32 possible two-party rules depending on the five binary choices listed above. As it turns out, however, none of these choices affect the outcome. All these two-party rules prove to be equivalent and lead to a settlement for the amount $\bar{D}$ :

Proposition 6. Under any two-party offer-of-settlement rule, the settlement will be $S_{*}^{*}=\bar{D}$.

Proof. We can prove this proposition using methods similar to those used in proving the preceding propositions. Because the proof is quite long, we have omitted it here, but it appears in the working paper versions of this article. $^{20}$

3) See Lucian A. Bebchuk \& Howard F. Chang. The Effect of Offer-of-Settlement Rules on the Terms of Settlement (Working Paper No. 6509. National Bureau of Economic Research 1998); Lucian A. Bebchuk \& Howard F. Chang, The Effect of Offer-of-Sertement Rules on the Terms of Setrlement (Discussion Paper No. 228, Harvard Law Sehool. John M. Olin Center for Law. Economies, and Business 1997). 
Remark. The basic intuition for this result is as follows. Once a party can invoke the offer-of-settlement rule, it can do at least as well as it can under a settlement for the amount $\bar{D}$. If both sides can invoke the rule, then the outcome must be a settlement for the amount $D$.

\section{SkEWEd Distributions and Disputes oner Liability}

The preceding analysis has assumed that $D$ is distributed athout its mean such that $m(D \leq D)=1 / 2$. That is, $D \leq D$ and $D=D$ are equally likely events. The distribution of $D$ may instead be skewed. however, so that $\operatorname{pr}(D \leq \bar{D}) \neq 1 / 2$. Suppose we relax our assumption that $\operatorname{pr}(D \leq \bar{D})=1 / 2$. Lemma 1, which did not turn on this assumption. would still hold. We would, however, need to reconsider the specific conclusions that we derived from the application of that lemma to particular offer-of-settlement rules.

Under one-party offer-of-settlement rules with one-sided cost shifting, it remains true that a party with an option to make a special offer would always choose to make such an offer. Furthermore, the offeror would still never be better off under a regime in which it could not make a special offer. It would no longer be true, however, that a special offer would always yield an outcome better than $\bar{D}$ for the offeror. ${ }^{21}$

Under one-party offer-of-settlement rules with two-sided cost shifting, the optimal special offer would no longer necessarily equal $\bar{D}$. Suppose the applicable rule makes a special offer mandatory. Then we can show the following.

PROPOSITION 7. If a one-party offer-of-settlement rule with two-sided cost shifting requires a party to make a special offer, then:

(a) If $\operatorname{pr}(D \leq \bar{D})>1 / 2$, then the settlement amount will be $S^{*}<\bar{D}$.

(b) If $\operatorname{pr}(D \leq \bar{D})<1 / 2$, then the settlement amount will be $S^{*}>\bar{D}$.

Proof. If $\operatorname{pr}(D \leq \bar{D}) \neq 1 / 2$, then the proof for proposition 4 is still valid up to and including equation (12), but now $S^{*}=\bar{D}$ does not solve (12). Suppose the offeror makes a special offer $S=\bar{D}$. If $\operatorname{pr}(D \leq \bar{D})>1 / 2$, then $B(S)$ evaluated at $S=\bar{D}$ is strictly less than $\bar{D}$. Therefore, lemma 1 implies that the optimal special offer $S^{*}$ for either party under two-sided cost shifting, given by the solution to (12), also must be strictly less than $\bar{D}$. By the same reasoning, if $\operatorname{pr}(D \leq \bar{D})<1 / 2$, then $B(\bar{D})>D$, and lemma 1 implies

${ }^{21}$ If $\operatorname{pr}(D \leq \bar{D}) \geq 1 / 2$, then an offer-of-settement rule favoring the defendant would still ensure a settlement less than $\bar{D}$. If $\operatorname{pr}(D \leq \bar{D})>1 / 2$. however. a rule favoring the plaintiff would not ensure a settlement greater than $\bar{D}$. The $S^{*}$ in $(9)$ could be less than $\bar{D}$. If $\operatorname{pr}(D \leq$ $\bar{D}) \leq 1 / 2$, then a rule favoring the plaintiff would ensure a settlement greater than $\bar{D}$. If $\operatorname{pr}(D \leq \bar{D})<1 / 2$. however, then a rule favoring the defendant would not ensure a settlement less than $\vec{D}$. The $S^{*}$ in (5) could be greater than $\vec{D}$. 
that the offeror would prefer to offer some $S^{*}>\bar{D}$, which would satisfy (12). Q.E.D.

Cases in which the defendant contests liability present a particularly important category of skewed distributions. The distribution of possible payoffs for the plaintiffs in such cases generally feature a discrete probability mass at $D=0$. With some technical modifications. we can extend our model to include payoff distributions with such diserete probability masses.

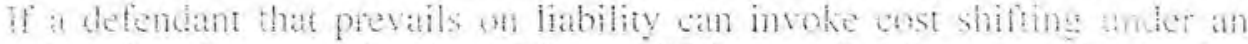
offer-of-settenent rule. then this possibility would skew the distriotion relevant for calculating the expected cost shifting at trial. The pusvibility that the defendant could prevail on liability may imply a median strictly below the mean. If so, then in these cases $\operatorname{pr}(D \leq \bar{D})>1 / 2$. It is also possible. however, that $\operatorname{pr}(D \leq \bar{D})<1 / 2$ when liability is in dispute.

To take a simple example, consider a case in which the parties agree on damages and dispute only liability. Let $L$ denote the damages that the defendant would pay the plaintiff if the court were to find liability. Let $p$ denote the probability that the plaintiff prevails on liability, with $0<p<1$. Thus, the distribution features a discrete probability mass of $p$ at $D=L$ and a discrete probability mass of $1-p$ at $D=0$. In this example, $\bar{D}=p L$, and $\operatorname{pr}(D \leq \bar{D})=1-p$. In this case, proposition 7 implies the following:

COROLlary. If a one-party offer-of-settlement rule with two-sided cost shifting requires a party to make a special offer, and the parties dispute only liability, then:

(a) If $p<1 / 2$, then the settlement amount will be $S^{*}<\bar{D}$.

(b) If $p>1 / 2$, then the settlement amount will be $S^{*}>\bar{D}$.

Finally, by the same reasoning used to prove proposition 6 , we can also show that the same outcomes would emerge under a two-party offer-ofsettlement rule. In particular, if both parties can make a special offer, settlement will always occur at the same $S^{*}$, because each party could ensure an outcome at least that favorable for itself by making a special offer. ${ }^{23}$ Therefore, both proposition 7 and its corollary would apply under any two-party rule.

\section{IMPLiCATIONS OF THE ANALySIS}

\section{A. Implications for Outcomes under the Existing Rule 68}

Our analysis enables us to identify the outcome under any given offer-ofsettlement rule. To illustrate, let us now apply this analysis to the outcomes

7. Thomas J. Campbell. Federal Rule of Civil Procedure 68: A Comment (Working Paper No. 31. Stanford Litw School. John M. Olin Program in Law and Economics 1987), argued that as a result, even under a two-party offer-of-settlement rule, the outcome would be biased in Jivor of the defendant.

"Specitically, the settlement will occur at the $S^{*}$ that solves equation (12). 
expected under the existing Rule 68. As noted, under Rule 68 as it currently stands. only the defendant has the option of making a special offer, and such an offer can trigger only one-sided cost shifting.

Assume for a moment that if the plaintiff obtained less at trial than the special ofter, the defendant would always get full reimbursement for all litigation costs. Under this assumption, the settlement amount wouk be the $S^{*}$ that solves equation $(5): S^{3}=\bar{D}+1 / 2\left(C_{4}-C_{p}\right)-C_{1} \operatorname{pr}\left(D \leq S^{*}\right)$.

The drow astotiption hovever, does mot now hold with respect to the existing Rute 68 for wo reasons. First, under the existing Ruic 68, cost shifting is whly pantal. Rembursement of expenses covers only coun fees and not atorneys fees. Let $\partial$ denote the fraction of the defendant's costs $C_{d}$ that the plaintiff would have to pay in the event of cost shifting.

Second in Delta Air Lines v. August, ${ }^{2+}$ the Supreme Court held that a defendant cannot invoke Rule 68 cost shifting if it prevails on liability. Thus, the defendant will be reimbursed only if the plaintiff prevails on liability but wins less in damages than the special offer $S^{*}$. Suppose that if the plaintiff prevails on liability, it always wins a positive amount. Thus, the defendant receives reimbursement if $D \leq S^{*}$, but only if $D>0$ also.

With these two limitations on reimbursement for the defendant, the settlement amount $S^{*}$ under the existing Rule 68 will solve

$$
S^{*}=\bar{D}+1 / 2\left(C_{\mathrm{d}}-C_{\mathrm{p}}\right)-\theta C_{\mathrm{d}} \operatorname{pr}\left(0<D \leq S^{*}\right) .
$$

Equation (13) reveals why Rule 68 currently has little practical significance and why defendants in many cases do not take advantage of the opportunity to make special offers. The only difference that the existing Rule 68 makes is the introduction of the cost-shifting term, $\theta C_{\mathrm{s}} \operatorname{pr}\left(0<D \leq S^{*}\right)$, in the equation for the equilibrium settlement amount. If $\theta$ is small, as it is likely to be under the existing rule, this term will be small even if the optimal special offer implies that $\operatorname{pr}\left(0<D \leq S^{*}\right)$ is positive.

Moreover, given that the defendant receives no reimbursement if it wins on liability, even the best special offer $S^{*}$ may imply that the probability of reimbursement equals zero. To illustrate, consider the example we have used above, with $\bar{D}=100, C_{\mathrm{p}}=60, C_{\mathrm{d}}=20$, and $\theta=1$, but suppose that the dispute is over only liability rather than damages. In particular, suppose that the plaintiff will win either 200 or 0 , and each outcome is equally likely. In this case, the solution to (13) would be $S^{*}=80$, which inplies that the probability of reimbursement is zero: $\operatorname{pr}\left(0<D \leq S^{*}\right)=0$. In fact, any special offer below 200 in this example would fail to trigger any Rule 68 cost shifting. Thus, under Rule 68 as it currently stands, the expected settement in this case would be the same with a special offer as without 
any special offer, and the defendant would have nothing to gain by invoking the rule.

Note that our analysis also enables identifying the settlement terms that would result from any of the various amendments of Rule 68 that have been proposed. Amendments have been proposed to (i) allow either party to make a special offer of settlement under Rule 68, (ii) include attorneys fees in the costs that may be shifted to the party rejecting the offer, and (iii) allow a defendant that wins on liability to invoke the rule. ${ }^{25}$ As is stugested by the preceding analysis, if these amendments bad been adopted, they would have considerably increased the use of Rule 68 offers. Furthermore, by using our lemma 1 and our propositions, it is possible to identify the effect that each of these amendments would have on the terms of settlement.

\section{B. Implications for the Design of Offer-of-Settlement Rules}

Our analysis has normative implications. The main effect of the law on outcomes is through its influence on settlement terms. Therefore, in designing an offer-of-settlement rule we should take into account the rule's potential effect on the terms of settlement. The model developed in this paper enables us to identify this effect.

One interesting implication of the analysis is the possibility of designing rules to eliminate or reduce the divergence between settlement terms and the expected judgment. While settlement terms are always chosen in anticipation of the expected judgment at trial, they might well diverge from it rather than mimic it. To be sure, the legal system, recognizing that settlement outcomes might diverge from the expected judgment, might set the expected judgment not at the level of the desired outcome but rather at the level that would result in settlement terms close to the desired outcome. ${ }^{26}$ There are still many contexts, however, in which it is reasonable to assume that the legal system has set expected judgments at the level that is equal to the desired outcomes. In such cases, it would be desirable to have settlement terms mimic the expected outcome of the trial - that is, to eliminate the divergence between these terms and the expected judgment.

As we have seen. one important possible source of divergence (though, as discussed below, not the only source) is asymmetric litigation costs. In the absence of an offer-of-settlement rule, settlement terms (compared with the expected judgment) tend to fivor the party with lower litigation costs.

25 See Preliminary Draft of Proposed Amendments to the Federal Rules of Civil Procedure. 98 F.R.D. 339, 361-63 (1983): 102 F.R.D. 425. 432-33. 437 (1984).

* See Bebchuk, supra note 7. One way in which the legal system might attempt to do so is by using treble dimages or punitive damages. 
Fee-shifting rules, we have seen, can be designed to address this effect of asymmetric litigation costs. Under the conditions that we have identified, it is possible to design rules that would move settlements toward the expected damages. Furthermore, the design of these rules does not require public officials to have information that would be difficult to obtain ex ante (for example, which party is expected to have lower litigation costs).

As we have shown. one way to get settements equal to the expected judgment is to require one of the parties io mathe as special offer with twosided cost shifting. As long as the cost shifting includes all litigation costs and is two-sided, this rule would produce an expocted setulement equal to the expected judgment, whether the rule requires the plaintiff or the defendant to make the offer. An alternative that yields the same outcome is to give each party an option to make a special offer. ${ }^{27}$ Note that Rule 68 as it stands currently is quite different from any of the rules that, under the identified circumstances, would ensure settlements that mimic the expected judgment. Under the existing Rule 68, (i) only the defendant may make a special offer, yet this offer is optional, (ii) the cost shifting is one-sided, and (iii) the cost shifting is only partial and does not include attorneys' fees.

While the potential use of offer-of-settlement rules to move settlement terms closer to the expected judgment is an interesting possibility, we are at this stage far from being in a position to make any recommendations concerning such use of these rules. First, we have shown how to ensure settlement terms equal to the expected judgment only in the situation in which the judgment is equally likely to be higher or lower than its expected value. Disputes over damages alone may come close to this situation, but cases that include a dispute over liability are unlikely to do so. To produce settlements equal to expected trial outcomes in cases of disputed liability, offerof-settlement rules would have to be more complex: we leave this subject to future research.

7 Other mechanisms can also produce the same outcome. Anderson, supra note 5. proposes two procedures, the "sincerity rule" and at "final offer auction." which would generate offers that mimic the expected award at trial. but to acheve this outcome, each procedure must include a prohibition on subsequent bargaining. The offer-of-settlement rules we describe would achieve this outcome without any prohibition on subsequent bargaining. One particularly simple procedure could also eliminate the bargaining advantages derived from asymmetric litigation costs: at the end of a trial. the court could divide the total litigation costs evenly between the plaintiff and the defendant. This cost-shifting rule, however. would require the party that spends less on litigation to bear some of the costs of the party that spends more, even if the party with higher expenditures loses at trial. Because this type of cost shifting would strike many as unfair, it seems unlikely to be adopted. The offer-ofsettlement rules we describe seem more appealing from a fairness perspective, because they shift the burden of litigation costs toward the party that was apparently too intransigent in settlement bargaining. Furthermore, as discussed below, offer-of-scttlement rules may have other desirable properties, such as increasing the probability of settement. 
Second, the effect that an offer-of-settlement rule has on settlement terms is not the only effect of the rule that should be taken into account in evaluating its merits. It would be important to consider also the rule's effect on the likelihood of settlement. ${ }^{28}$ To focus on settlement terms, we assumed symmetric information, which ensured that all cases will settle (with the only question being for how much). ${ }^{29}$ It should be noted. however, that using a model with asymmetric information. Kathryn Spier has demonstrated that in the case in which the parties dispute mily danuges and the flutgment is equally likely to exceed or to fall below its mean, a centain two-punty offer-of-settlement rule with two-sided cost shitting will actually maximize the itielihood of settement. ${ }^{30}$

Furthermore, an assessment of an offer-of-settlement rule should take into account also the rule's effect on the level of litigation costs in the event of trial. In our model, we took this level to be given exogenously. As is true for any fee-shifting rule, however, an offer-of-settlement rule would increase the litigation costs in a trial, because in the event of trial, each party would know that, with some probability, it would not have to bear fully its litigation costs.

Finally, even focusing only on the terms of settlement, it should be noted that our model has focused on only one reason-namely, asymmetric litigation costs - for settlement terms to deviate from the expected judgment. In particular, we have assumed that all litigants are risk neutral, cannot credibly commit to a strategy that insists on a disproportionate share of the gains from settlement, and have an equal ability to make settlement offers. Relaxing these assumptions would introduce other sources for divergence between the terms of settlement and the expected judgment-such as differences between the parties in their ability to bear risk or to commit to a certain bargaining position. The presence of these other sources of divergence suggests that much analysis must be done before we know which rules and institutions would best align settlement outcomes with the ex-

25 Indeed, a comprehensive normative analysis of an offer-of-settlement rule would include an evaluation of the effects not only on the parties incentives to settle but also on the plaintiff's incentives to file suit and on the defendant's incentives to comply with the law (see Hylton, supra note 5).

${ }^{2}$ Models of litigation and settement incorporating asymnetric information show that such asymmetries hinder settlement and create some positive probability that settement negotiations break down and the parties go to trial. See, for example. Lucian A. Bebchuk, Litigation and Settlement under Imperfect Information, 15 RAND j. Econ. 404 (1984); Jennifer F. Reinganum \& Louis L. Wilde. Settlement, Litigation, and the Allocation of Litigation Costs, 17 RAND J. Econ. 557 (1986).

${ }^{3}$ See Spier, supra note 5. She presents another model. however, that indicates that an ofter-of-settlement rule can decrease the probability of settlement if the litigants disagree about liability and the damages are known. 
pected judgment. We hope that future work will pursue this agenda for research.

\section{CONCLUSION}

This paper has analyzed the effect of offer-of-settlement rules on the terms of settlement. We first set forth a general result that enables us to idemify the settlement amount under any such rule. We have then applied this result to derive the outcome under the most important of these rules, showing that a large set of seemingly different rules produce identical setthements. The identified effects of these rules on settlement terms have implications, which we have discussed, for any positive or normative evaluation of the rules. 